\title{
Strategies for the Creative Economy Development of Urban Fishermen in East Java: A Multivariate Analysis Perspective
}

\author{
Achmad Yanu Alif Fianto $^{1 *}$, Candraningrat ${ }^{2}$ \\ 1, 2 Management Department, Faculty of Economy and Business, Universitas Dinamika, Indonesia \\ *Corresponding author email: achmadyanu@gmail.com
}

\begin{abstract}
This article is one part of research on strategies for developing the creative economy of urban fishermen in East Java Province. The research in this article focuses on efforts to prove the influence of Word of Mouth, Motivation, Destination Awareness, Destination Image, Destination Branding, Market Attractiveness, Purchasing Power and Location on Interests Visiting from tourists to the beach tourism area in East Java. This research uses survey techniques to collect data from 250 respondents. Data collection techniques in this research use accidental sampling by distributing questionnaires to higher education students in East Java who have an interest in going on tourist trips on the beaches in East Java. This research adopts Structural Equation Model-Partial Least Square as a data analysis technique. This research has proven that Word of Mouth, Motivation, Destination Awareness, Destination Image, Destination Branding, Market Attractiveness, Purchasing Power and Location have a significant influence on Visiting Interest.
\end{abstract}

Keywords: Creative Economy; Marine Tourism; Visit Intentions; Word of Mouth; Destination Attractiveness.

\section{INTRODUCTION}

Indonesia has a very wide area supported by diverse natural resources that have the potential to be processed and utilized[1]. In addition, the country of Indonesia is also rich in regional cultural arts, customs, historical relics and no less interesting is the beauty of its natural panorama which has enough potential to be well developed. It turns out that tourism can be relied upon to improve people's welfare and national development[2].

There are also many tourist objects in Indonesia that have been famous not only domestically and abroad[3]. The coastal area and marine resources of East Java Province are developing very rapidly [4]. Moreover, it lies in a strategic position so that it has economic benefits in the form of foreign exchange from exports. However, there are also negative impacts on the waters especially the sea area and coastline[5].

This is if there is no action will occur continuously, which is due to the lack of public awareness of the environment, such as fishing, fish farming, and the tourism industry based solely on economic benefits[3]. However, some of these things can bring prosperity to the coastal community if done properly[2]. There are three social processes that can be carried out to improve the economic development of coastal communities in the coastal regions of East Java Province[6].

First, make better changes continuously[5]. Second, increase the amount of income per capita for the long term. Third, institutional system changes in all fields, such as economic, social, legal, political, and cultural, especially in the institutional field. Thus, an increase in the economy of the coastal community will be seen as a change which includes several factors that can increase 
the economic change in the coastal community. The real situation is that the condition of coastal communities is still relatively economically or socially behind when compared to other parts of society[7]. The condition of coastal communities in various regions is generally reflected in situations such as the low quality of human resources, backward socio-cultural aspects, poverty and the function of the existence of business groups that do not play a significant role. This fact needs serious attention because there is an imbalance between the economic potential of the sea and the improvement of people's welfare[8].

The economic improvement in East Java did not have an impact on improving the economy of coastal communities[9]. So that marine commodities, especially all types of advertisements used as anchovies, salted fish, crackers, shredded meatballs, seaweed, fish farming and other commodities have not been proven to have participated in the economy of coastal communities[10].

Thus, it is not balanced because it does not have an impact on social income, such as high investment values but unemployment rates do not decrease, high development budgets but poverty remains, and so on, which according to the circumstances[11]. East Java has a fairly long coastline. The results of the maritime potential in this region are relatively large such as those in the Banyuwangi, Probolinggo, Pasuruan and even Surabaya areas[9]. The area is the biggest fish producer in East Java and even fish catch in the area can be a provider of fish needs in East Java Province[7]. However, this is not in line with the improvement in the welfare of the fishing community, let alone worsened by a continuous decline in catches[8].

Therefore, the development of the coastal economy in East Java is more directed towards the development of the creative economy, especially the development of the tourism sector[4]. The tourism sector is one of the strategic sectors in driving the Indonesian economy and becoming part of the global economy[9]. The ongoing 3T revolution including transportation, telecommunications, tourism, shows that tourism activities have become one of the forces capable of accelerating world integration in economic integration and human movement across regions and even across countries[10].

The concentration of the development of tourism in East Java is based on natural and cultural attractions. Future developments are expected to follow the current pattern. The still centralized structure of tourism activities in East Java results in a lack of ability to service existing tourism facilities and a decline in the quality of the tourism environment due to the use that exceeds the carrying capacity.

The problem now is how to develop strategies so that people can enjoy the results of these developments. Certainly it is very ironic if something happens cultural products develop rapidly, while the welfare of community members who support it never increases. Whatever form of development of cultural tourism needs to be remembered that the community is not for tourism, but rather it must be on the foundation of the principle of "tourism for the people". This principle prioritizes the interests of the community rather than the needs of the community. Because the community as the subject of tourism, the tourism development policies and plans must be directed in such a way that within each member of the community grows a sense of ownership of existing tourist assets around them.

Tourism becomes one of the prima donna for countries in increasing their sources of income outside of oil and gas and taxes. Currently Indonesia as a developing country has begun to promote its country to attract the eyes of other worlds, this is intended to make Indonesia increasingly popular for citizens / residents of other countries to visit Indonesia. Promotions conducted are selling the diversity of Indonesian tourism and culture, this has been responded positively to the number of tourists from foreign countries visiting Indonesia.

Indonesia which has abundant cultural diversity and tourism is able to overcome the fundamental problems by strengthening the economy of foreign exchange earnings / regional income. Therefore, as a country that has abundant diversity, Indonesia can develop its potential, for example in terms of tourism because tourists visiting Indonesia seek or enjoy the beauty of Indonesian tourism so that it gives a domino effect to both domestic and foreign countries, if from abroad our country is increasingly well-known then for the country our country can add foreign exchange to raise the welfare of the people that exist today.

Tourism has a big role in national development. Because in addition to generating income and at the same time as a foreign exchange earner, the tourism sector is closely related to foreign investment. Tourists who come to Indonesia include those who have business relations with Indonesia.

Tourism business is an activity aimed at providing tourism services or providing or commercializing tourist objects and attractions, tourism goods business and other businesses related to the said field. The tourism industry is a set of organizations, both government and private, that are involved in the development, production and marketing of a service product to meet the needs of people who are traveling.

Tourism in the regions is very much if able to take advantage of the existing potentials, the government and local communities help each other in its development so that it will raise the economic, cultural and educational aspects of the area[12]. Tourism is very capable in overcoming welfare problems if it is developed professionally[13].

In the development of tourism, it is not only the 
government that does it alone but other parties also contribute to the development of companion infrastructure, this is to increase income from the economic sector[14]. The stages of tourism planning begin with the development of regional tourism which includes the physical development of tourist objects and attractions[15]. After that is done, we will be able to see how the development of the number of tourists visiting if it turns out to reach the targets that have been set next will think of a priority system. For this development approaches need to be made with existing tourism organizations (government and private) and related parties which are expected to support the continued development of the area's tourism.

The development of an area can be adjusted by the regional government with the potential and uniqueness of each region. This is an excellent opportunity for local governments to prove their ability to exercise authority that is the right of the region. The progress or failure of an area is determined by the ability and willingness to implement, namely the local government. Regional governments are free to create and express themselves in order to develop their regions, of course by not violating the legal provisions, namely legislation.

The tourism industry plays a role in developing the local economy of the community, regional economic activity will increase marked by the existence of people who sell or trade, the creation of labor-intensive industries that can open jobs that can create income for the population. The tourism economy is an activity that is related to the phenomenon of tourism to maximize resources in the form of capital, human, and nature in the hope of obtaining the results of tourism products in the form of maximum goods and services (Suartini and Utama, 2013).

Because of that, tourism needs proper strategies to have great potential that will succeed and bring a better change in various fields. Strategy is an important element in facing challenges. The success of facing challenges depends on the application of the strategy. The tourism object does not have a formal strategy in attracting tourists. This research is divided into two parts, where the first part aims to identify the factors that influence the sustainability of tourism in the coastal regions of East Java divided by factors of strength, weakness, challenges, and opportunities. While the second part discusses the development of tourism development strategies based on the factors identified in the first part.

\section{LITERATURE REVIEW}

\subsection{Interest in Visiting}

Interest explains about individual desires to behave. Interest itself becomes the basis for individuals to make decisions. If related to the decision to visit, then the interest in visiting can be explained as a feeling or desire to visit a place for a certain reason. Interest in visiting according to Hermansyah and Waluya (2012) through five phrases namely (1) there is a need; (2) searching for information; (3) determine the decision; (4) preparing a trip; and (5) evaluation of satisfaction with visits that have been made. Interest in visiting can be explained through four indicators, namely (1) Transactional interest, explaining the tendency of individuals to buy products (2) Referential interest, explaining the tendency of individuals to refer products or tourist attractions to others (3) Preferential interest, explaining behavior individuals who have a primary preference for the product or tourist site concerned (4) Explorative interest, explains the behavior of individuals who are always looking for information about products or tourist attractions of interest and looking for information to support the positive nature of the tourist attractions concerned.

\subsection{Word of Mouth}

Word of mouth is a form of communication that occurs by word of mouth that contains positive information about a product, service or tourist site. Further explained that word of mouth became one of the references trusted by the public as a reliable source of information.

Word of mouth has become a source of information that according to the community as a source of credible information, so this makes word of mouth as one of the more effective marketing media compared to mass media or advertisements. When associated with visiting interests, word of mouth is a form of effort to provide information which is then discussed by the public so as to generate interest in visiting tourists. Word of Mouth contains a positive story which then has an element of invitation so that other people have an interest in visiting the tourist attractions discussed. Word of mouth can be explained through two indicators, namely

(1) Volume that explains often information that is revealed through word of mouth (2) Dispersion that explains the number of people involved in word of mouth activities.

\subsection{Motivation}

Motivation is an impulse which then causes the individual to act to do certain things in order to reach the desired thing. Motivation is often associated with there needs, one individual needs. Individual needs consist of biological needs and psychological needs. In Maslow's theory of needs hierarchy, it is also explained that needs become a tool to encourage motivation to arise in individuals. According to Maslow's hierarchy of needs, individual needs that can encourage motivation arise consisting of (1) physiological needs, which are related 
to the need for life (2) security needs, which are related to the understanding of safety literally (3) social needs which include the need to interact (4) Needs of prestige related to self-esteem (5) Needs of self-actualization related to efforts to recognize oneself. Related to the interest in visiting, there is an influence between motivation on the interest of visiting tourists. Before going on a tour of travel, a person needs a reason, which then becomes a motivation in the form of motivation to further increase interest in visiting tourist attractions.

\subsection{Destination Awareness}

Destination awareness is explained as the knowledge or public awareness of the intended destination and first comes to mind. In the decision-making process, destination awareness has a role to increase the possibility of individuals considering tourist sites that do not have a relationship with other tourist places that individuals want to go to. Destination awareness is related to individual emotions which are then able to form loyalty to a place. Therefore, it can be explained that the better the awareness of tourists about tourist attractions, the greater the interest in visiting the tourist attractions. Destination awareness can be classified into two, namely brand recognition and brand recall. The explanation of the two categories is (1) Brand recognition which explains the ability of the community to confirm the characteristics of tourist attractions. (2) Brand recall that explains the ability of the community to generate experiences about the tourist attractions concerned.

\subsection{Destination Image}

Destination image is explained as an impression or impression of the community towards a place. This impression can be formed because there is information that has been processed by individuals about the place in question. Destination image is formed from the results of individual knowledge about a place which is then stored as individual thoughts about a tourist spot. In this destination image is formed through destination awareness. People tend to have a great interest in visiting when the place has a good image. Destination image has a positive influence on the interest of visiting tourists. Destination image consists of two elements, namely (1) Cognitive imagery describing beliefs about information about the destination (2) Affective imagery describing emotional assessment of the perceived matter of the destination.

\subsection{Destination Branding}

Destination branding is part of the characteristics of a tourist spot which is illustrated through logos or other forms that are easily remembered by tourists. Destination branding contains a positive invitation to prospective tourists to visit tourist attractions. The more attractive the destination brand that is formed, the greater the community becomes interested and has an interest in visiting the relevant tourist attractions. Several factors that are considered in building destination branding can be divided into four, namely (1) Natural conditions of tourist attractions (2) Regulations on the validity of tourist attractions (3) Economic conditions of tourist attractions (4) Communities as agents of developing tourist attractions.

\subsection{The Tourist Attraction}

The tourist attraction can be explained as a prime mover that can encourage tourists to visit a place. The tourist attraction is all aspects contained in tourist attractions that can attract people to visit. These aspects include the uniqueness, beauty, and diversity of natural wealth. The attraction of a place can be explained through three things, namely (1) Interesting attractions (2) Affordable accessibility (3) Complete amenities. When associated with visiting interests, attractiveness is one reason for people to have an interest in visiting a place.

\subsection{Purchasing Power}

Purchasing power has an influence on purchases made by the public. Purchasing power itself describes the ability of individuals to buy a product or service. Purchasing power has an influence on tourist behavior to visit tourist attractions. The smaller the purchasing power of a person can discourage visiting a tourist attraction. There are three things that affect purchasing power, namely (1) individual income (2) tastes of a product. (3) Product prices.

\subsection{Location}

Location is related to consumer characteristics. This explains that the easier the location of the tourist attractions to reach, the more people want to visit. Tourists consider the location as a reason to visit, because increasingly difficult to reach the location of tourist attractions can discourage tourists from visiting. The factors considered by the community include (1) easy accessibility (2) good visibility (3) non-congested traffic

(4) available parking space (5) expansion or having vacant land for development (6) environment clean and good (7) Competitions arising from other tourist attractions in the vicinity (8) Government Regulations regarding the eligibility of places visited.

\section{RESEARCH METHODOLOGY}

This study uses a quantitative approach. This study uses data in the form of survey answer numbers distributed to the study sample and analyzed using 
statistical analysis techniques. The quantitative approach is used because the data used in this study can be processed using statistics. The research approach uses multiple linear regression methods.

This research was conducted in several coastal tourism areas in East Java Province. The population studied in this research are people who have visited several of these coastal tourism areas. Then the sampling is done using purposive sampling, which uses criteria (1) Minimum age of visitors who become respondents is 15 years, because it is assumed to have been able to answer and analyze the questions and information provided. (2) If the visitor is with the family, then the respondent is the head of the family. (3) If visiting in the context of a school or company event, then the respondent is the group leader as an individual who decides on the object visited as a representative, and also chooses one member of the group to be the respondent.

After that, to count the number of samples using the formula unknown population, so the research sample is known to be 200 people. Data collection in this study used a questionnaire instrument with a measurement scale in the form of a Likert scale. The Likert scale category used consists of five, namely: strongly agree, agree, disagree, disagree, to strongly disagree. After the data is collected then it is analyzed using structural equation model-partial least square analysis.

In addition, this research is also descriptive research. The main focus in this research is anyone who is involved in the development of tourism potential in the coastal region in East Java, which is focused on the areas of Surabaya, Sidoarjo, Pasuruan, Probolinggo and Banyuwangi. The unit of analysis used in this study is institutions and individuals. The institutions that were used as the unit of analysis in this study were the Office of Culture, Tourism, Youth and Sports; Fisheries Service and other related government agencies; local community; and business actors.

Data in this study were collected through observation, documentation and in-depth interviews. Data validity checking using data source triangulation techniques is done by comparing the results of observational data with interview data and interview results with related documents, and data analysis through data reduction, data presentation and drawing conclusions.

\section{RESULTS AND DISCUSSIONS}

\subsection{Evaluation of Measurement Models}

Testing the measurement model is testing the relationship between variables and indicators. This test consists of two stages which include testing on convergent validity and discriminant validity measurement. Convergent validity can be tested with three stages which include the validity of the indicator, construct reliability and the value of Average Variance Extracted (AVE). The validity of the indicator can be determined from the factor loading value. If the factor loading value of an indicator is greater than 0.5 with a tstatistic value greater than 2.0; then the indicator can be assessed as a valid indicator. On the other hand, if the loading factor value is smaller than 0.5 with a $t$ value of statistics smaller than 2.0; then the indicator must be excluded from the model. The loading factor explains the correlation between these indicators with their variables. The higher the correlation, it can be concluded that the indicator has a better level of validity.

The next test of convergent validity is testing the reliability of the construct by referring to the results of the composite reliability or Cronbach's alpha output values. The requirement to be called reliable must have a composite reliability or Cronbach's alpha value of more than 0.70 . From the output of the following table shows that all constructs have a composite reliability or cronbach's alpha value of more than 0.70 so that it can be called a reliable construct. The final test of convergent validity refers to the results of AVE output. A variable or construct judged to be good must have a AVE value of more than 0.50. Based on the following table, all AVE values were found to have values greater than 0.50 .

The measurement of discriminant validity is carried out in two stages, namely by looking at the value of cross loadings and comparing the square of the correlation between the construct and the AVE value or the correlation between the construct construct with the root AVE. The criteria in cross loading are emphasized on each indicator that measures the construct must correlate higher with the construct compared to other constructs in the research model studied.

Based on the cross loading value, it can be seen that each indicator has a higher correlation with each construct compared to the other constructs so it is said to have relatively good discriminant validity. The next test is comparing the correlation with the root construct AVE.

\subsection{Evaluation of Structural Models}

After checking the measurement model is fulfilled, the next step is testing the structural model. This test includes testing the significance of the relationship path or research hypothesis and the value of $\mathrm{R}^{2}$. Based on the table that shows the Path Coefficient it can be concluded that all path relationships in this research are significant because they have a t-statistic value greater than 2.0.

\section{CONCLUSION}


In innovative natural ventures specifically, the importance and esteeming of products are controlled by the shoppers' coding and unraveling of images, and their consumption and utilization are thusly unique in relation to utilitarian merchandise. Discussing inclination discernment gets troublesome. This research adds to an upgraded logical and perceptive intensity of the study of economic aspects when concentrating on the highdevelopment creative economy.

In the context for developing strategies for the creative economy development of urban fishermen in East Java, Indonesia in the perspective of multivariate analysis, this research proves that Word of Mouth, Motivation, Destination Awareness, Destination Image, Destination Branding, Market Attractiveness, Purchasing Power and Location has a partial effect on intention to visit. Not only that, this research also proves that Word of Mouth, Motivation, Destination Awareness, Destination Image, Destination Branding, Market Attractiveness, Purchasing Power and Location also have a simultaneous influence on intention to visit.

\section{ACKNOWLEDGMENT}

The author would like to thank the Indonesian government for the geneours funding of the research in a grant scheme of which this research as a part. The authors also thank the reviewers and the editors of this conference for the valuable direction for this paper perfections.

\section{REFERENCES}

[1] R. Santoso, R. Shinta, and A. Y. A. Fianto, "Composing Marketing Mix for Better Destination Brand in Jawa Timur, Indonesia," Maj. Ekon., vol. XXIV, no. 1411, pp. 158-167, 2019.

[2] R. Santoso, R. Shinta, and A. Y. A. Fianto, "Pengaruh Bauran Pemasaran Jasa terhadap Keputusan Berkunjung ke Wisata Bahari Jawa Timur," Manaj. dan Bisnis, vol. 4, pp. 1-14, 2019.

[3] R. Santoso and A. Y. A. Fianto, "Pengaruh Marketing Mix Produk Jasa terhadap Keputusan Berkunjung Wisata Bahari Jawa Timur," Kinerja, vol. 17, no. 1, pp. 69-79, 2020.

[4] D. Y. Riyanto, N. Andriyanto, A. K. Riqqoh, and A. Y. A. Fianto, "A Conceptual Framework for Destination Branding in Jawa Timur, Indonesia," Maj. Ekon., vol. XXIV, no. 1411, pp. 149-157, 2019.

[5] A. Y. A. Fianto, "Satifaction As Intervening For The Antecedents Of Intention To Revisit: Marine Tourism Context In East Java," Relasi, vol. 16, no. 1, pp. 179-207, 2020.

[6] A. Y. A. Fianto, "The Antecedents of Purchase
Decision for Hijab Fashion Products," Manajemen, vol. 12, no. 1, pp. 154-165, 2020.

[7] S. Lauwrentius, "Penciptaan City Branding melalui Maskot sebagai Upaya untuk Mempromosikan Kabupaten Lumajang," Unpublished Undergraduate Thesis, Visual Communication Design, 2015.

[8] A. Marzuqi, "Penciptaan Motif Batik sebagai Ikon Kabupaten Lumajang," Institut Bisnis dan Informatika Stikom Surabaya, 2015.

[9] R. D. Pinasti, A. Y. A. Fianto, and W. Hidayat, "Penciptaan Buku Komik Sebagai Upaya Pengenalan Permainan Tradisional Kepada Remaja," Art Nouv., vol. 4, no. 1, 2015.

[10] A. Jafar, A. Y. A. Fianto, and S. P. Yosep, "Penciptaan Buku Ilustrasi Permainan Tradisional Sebagai Upaya Pelestarian Warisan Budaya Lokal," Art Nouv., vol. 3, no. 1, 2014.

[11] E. Y. Ikawira and A. Y. A. Fianto, "Penciptaan Buku Ilustrasi Legenda Reog Sebagai Upaya Mengenalkan Budaya Lokal kepada Anak-Anak," Art Nouv., vol. 3, no. 1, 2014.

[12] T. MacNeill and D. Wozniak, "The economic, social, and environmental impacts of cruise tourism," Tour. Manag., vol. 66, pp. 387-404, 2018, doi: 10.1016/j.tourman.2017.11.002.

[13] M. Papageorgiou, "Coastal and marine tourism: A challenging factor in Marine Spatial Planning," Ocean Coast. Manag., vol. 129, pp. 44-48, 2016, doi: 10.1016/j.ocecoaman.2016.05.006.

[14] P. F. M. Lopes, L. Mendes, V. Fonseca, and S. Villasante, "Tourism as a driver of conflicts and changes in fisheries value chains in Marine Protected Areas," J. Environ. Manage., vol. 200, pp.123-134, 2017,

doi: 10.1016/j.jenvman.2017.05.080.

[15] N. L. B. Knowles, "Targeting sustainable outcomes with adventure tourism: A political ecology approach," Ann. Tour. Res., vol. 79, no. September, p.102809, 2019, 10.1016/j.annals.2019.102809. doi: 